\title{
Pengembangan LKPD Berbasis Problem Based Learning (PBL) dengan Penguatan Karakter Kerja Keras Subtema Indahnya Persatuan dan Kesatuan di Negeriku untuk Kelas IV SDN Banggle 02 Kabupaten Blitar
}

\author{
Anggia Diah Wahyu Mastuti, Lilik Bintartik*, Sumanto \\ Universitas Negeri Malang, Jl. Semarang No. 5 Malang, Jawa Timur, Indonesia \\ *Penulis korespondensi, Surel: lilik.bintartik@fip.um.ac.id
}

Paper received: 1-4-2021; revised: 22-4-2021; accepted: 29-4-2021

\begin{abstract}
The purpose of this development research is to produce a valid Problem Based Learning LKPD based on material experts, instructional materials experts, and users as well as practical and interesting according to students. This product can be used as additional teaching material on the Theme of Diversity and Unity of My Country The Subtheme of the Beautiful Unity and Unity in my Country learning 1 and 2. The development of this LKPD uses the research method of Borg \& Gall modified by Sugiyono. The steps are 1) potential and problems, 2) data collection, 3) product design, 4) product validation 5) product revision, 6) product trial, 7) product revision, 8) trial use, and 9) revision product. The results of the product validation were stated to be very valid, with an average rating of 94 percent material experts, subject matter experts, and 100 percent users. Student responses about practicality and attractiveness reached 96 percent and 100 percent. Based on all of the assessment results it can be concluded that PBL-based LKPD products are very valid, very practical, very interesting, and can be used without revision.
\end{abstract}

Keywords: lkpd; problem based learning; primary school

\begin{abstract}
Abstrak
Tujuan penelitian pengembangan ini menghasilkan LKPD berbasis Problem Based Learning yang valid menurut ahli materi, ahli bahan ajar dan pengguna serta praktis dan menarik menurut peserta didik. Produk ini dapat digunakan sebagai bahan ajar tambahan pada Tema Keragaman Persatuan dan Kesatuan Negeriku Subtema Indahnya Persatuan dan Kesatuan di Negeriku pembelajaran 1 dan 2. Pengembangan LKPD ini menggunakan metode peneltitian dari Borg \& Gall yang dimodifikasi oleh Sugiyono. Langkah-langkahnya yaitu 1) potensi dan masalah, 2) pengumpulan data, 3) desain produk, 4) validasi produk 5) revisi produk, 6) uji coba produk, 7) revisi produk, 8) uji coba pemakaian, dan 9) revisi produk. Hasil validasi produk dinyatakan sangat valid, dengan rata-rata penilaian ahli materi 94 persen, ahli bahan ajar dan pengguna 100 persen. Respon peserta didik tentang kepraktisan dan kemenarikan mencapai 96 persen dan 100 persen. Berdasarkan seluruh hasil penilaian dapat disimpulkan bahwa produk LKPD berbasis PBL sangat valid, sangat praktis ,sangat menarik, dan dapat digunakan tanpa revisi.
\end{abstract}

Kata kunci: lkpd; problem based learning; sekolah dasar

\section{Pendahuluan}

Saat ini pendidikan karakter sangatlah penting untuk membentuk generasi penerus bangsa yang tidak hanya pandai di aspek kognitif, tetapi juga memiliki karakter yang baik. Penanaman karakter tersebut hendaknya dimulai dari tingkat Sekolah Dasar (SD). Menurut Lickona (dalam Sudrajat,2011:49) pendidikan karakter adalah suatu usaha yang disengaja untuk membantu seseorang sehingga ia dapat memahami, memperlihatkan, dan melakukan nilai-nilai etika. Salah satu penanaman karakter pada kurikulum 2013 bisa melalui 
penggunaan model pembelajaran PBL (Problem Based Learning). Menurut Fitri \& Octarini (2017:88) model pembelajaran PBL merupakan model pembelajaran yang di awali dengan sebuah permasalahan kemudian diikuti oleh proses pemecahan masalah yang lebih didominasi oleh peserta didik itu sendiri. Selain mendorong peserta didik untuk berfikir kritis dalam menyelesaikan masalah dan menemukan solusi terbaik juga melatih peserta didik untuk bersikap kerja keras di dalam proses pembelajaran maupun di luar proses pembelajaran. Sikap kerja keras tersebut merupakan salah satu dari 18 karakter yang harus ada di dalam proses pendidikan.

Hasil wawancara pada tanggal 10 Desember 2019 menunjukkan fakta bahwa pembelajaran di SD tersebut sejauh ini sudah baik dan lancar, tampak guru sudah tepat waktu pada saat mengajar, peserta didik yang selalu mengumpulkan tugas dari guru dengan tepat waktu, dan pembelajaran yang sudah menggunakan kurikulum 2013. Bahan ajar yang digunakan pada saat proses pembelajaran yaitu menggunakan buku siswa. Guru kelas IV tersebut juga mengungkapkan bahwa peserta didik kadang-kadang masih merasa bingung dengan materi yang ada di buku siswa, karena di kelas 3 dahulu masih menggunakan KTSP yang mata pelajarannya berdiri sendiri, tidak seperti di K13 yang pembelajarannya melibatkan beberapa mata pelajaran yang diikat dalam tema-tema. Sehingga kebingungan tersebut mengakibatkan peserta didik kurang aktif dalam pembelajaran.

Minat peserta didik pada saat proses pembelajaran juga masih kurang menunjukkan sikap kerja keras, guru kelas IV mengungkapkan meskipun selalu tepat waktu dalam mengumpulkan tugas tetapi pada saat menjawab soal-soal atau tugas dari guru, peserta didik cenderung menjawab seadanya tanpa benar-benar memikirkan pemecahan masalah dari soal tersebut yang terpenting yaitu cepat selesai. Selain itu peserta didik masih sering bertanya kepada guru saat mengerjakan tugas, sehingga sikap kerja keras dalam menyelesaikan soalsoal masih kurang. Padahal untuk anak jenjang sekolah dasar menurut Marjono (dalam Ahmad Susanto, 2016) hal yang harus diutamakan adalah cara mengembangkan sikap pantang menyerah dan berfikir kritis mereka terhadap suatu masalah, tidak hanya menghafal materi dan memandang nilai sebagai tolak ukur keberhasilan pembelajaran. Hasil wawancara dengan guru juga menunjukkan bahwa guru belum pernah memodifikasi buku siswa, sehingga peserta didik belum pernah menggunakan LKPD yang berbasis PBL saat pembelajaran berlangsung.

Hasil observasi di lapangan tentang buku ajar yang digunakan menunjukkan perlunya penambahan kegiatan pada Tema Keragaman Persatuan dan Kesatuan Negeriku Subtema Indahnya Persatuan dan Kesatuan Negeriku pembelajaran 1 dan 2. Seperti bacaan terkait teks bacaan non fiksi dibuat berbeda, terkait dengan manfaat magnet belum ada percobaan sebaiknya diberikan minimal 1 percobaan, terkait dengan cara membuat magnet sederhana belum ada sebaiknya ditambahkan salah satu cara membuat magnet sederhana, ditambahkan juga kegiatan menemukan pengetahuan, bukan menerima pengetahuan saja, langkah-langkah membuat kolase dan mozaik ditemukan sendiri oleh peserta didik, tidak membaca dari buku siswa, dan menambahkan percobaan tentang besar kecilnya gaya gesek.

Hasil observasi di lapangan tentang proses pembelajaran di kelas yaitu pada saat proses pembelajaran terlihat peserta didik lebih dominan mendengarkan penjelasan dari guru, sesekali berdiskusi dengan teman sebangku, lalu peserta didik melakukan tanya jawab dengan guru. Peserta didik menerima materi tersebut berdasarkan penjelasan dari guru melalui buku pegangan yang didalamnya berisi materi-materi yang akan diajarkan pada saat itu. Setelah 
mendengarkan penjelasan dari guru, biasanya peserta didik diminta mengerjakan kegiatan yang ada di dalam buku siswa dengan waktu yang sudah ditentukan. Hal itulah yang menjadi salah satu penyebab peserta didik lebih bergantung kepada guru saat mengerjakan kegiatan dibuku siswa. Sehingga kegiatan pembelajaran tersebut membuat peserta didik cepat merasa bosan dan cenderung kurang fokus dalam pembelajaran. Terkadang jika pembelajaran di kelas sudah cukup lama berlangsung peserta didik menjadi ramai sendiri dan bermain dengan benda-benda di sekelilingnya. Jika nantinya sudah terdapat LKPD berbasis PBL, buku siswa akan tetap digunakan sebagai tambahan sumber belajar lainnya. Berdasarkan hasil observasi dan wawancara tersebut dikembangkan bahan pembelajaran berupa LKPD berbasis PBL dengan penguatan karakter kerja keras.

Penelitian yang menggunakan bahan pembelajaran serupa yaitu Pengembangan Bahan Ajar Berbasis PBL berupa LKPD disertai Nilai Karakter oleh Rusmalinda, Santoso, \& Pratiwi n.d., .Hasil penelitian menunjukkan bahwa LKPD mendapat nilai kelayakan dari ahli desain 89,58\% termasuk kedalam kriteria sangat layak, ahli materi 85\% termasuk kedalam kriteria sangat layak, dan peserta didik sebesar $86 \%$ termasuk kedalam kriteria sangat layak. Berdasarkan hasil penelitian yang diperoleh dapat disimpulkan bahwa LKPD yang telah dikembangkan sangat layak untuk digunakan sebagai salah satu bahan ajar dalam proses pembelajaran. Kelayakan produk tentunya tidak terlepas dari masukan dan saran para validator ahli.

Tujuan dari adanya pengembangan LKPD yaitu membantu siswa untuk belajar menyelesaikan masalah dengan penuh sikap kerja keras. Menurut Yaumi (2014) cara mengembangkan dan mengintegrasikan nilai-nilai karakter dan budaya bangsa bisa dilakukan melalui aktivias pembelajaran tanpa harus membahas satu persatu nilai-nilai yang dimaksud secara terpisah. Pengembangan LKPD ini disebut "Pengembangan LKPD Berbasis Problem Based Learning (PBL) dengan Penguatan Karakter Kerja Keras Subtema Indahnya Persatuan dan Kesatuan Negeriku untuk Kelas IV SDN Banggle 02 Kabupaten Blitar". Kelebihan dari pengembangan LKPD berbasis PBL ini yaitu dapat melatih peserta didik meningkatkan sikap kerja kerasnya dengan cara guru mendorong peserta didik ke dalam suatu permasalahan dan mereka diminta untuk berusaha memecahkan masalah yang berkaitan dengan materi tersebut.

\section{Metode}

Produk LKPD berbasis PBL menggunakan metode penelitian R\&D (Research and Development), yang berpacu pada metode pengembangan milik Borg and Gall. Dikarenakan adanya keterbatasan waktu dan biaya pelaksanaan penelitian dan pengembangan yang menggunakan model Borg and Gall terbatas hanya sampai pada 9 tahapan, yaitu 1) potensi dan masalah, 2) pengumpulan data, 3) desain produk, 4) validasi produk, 5) revisi produk, 6) uji coba produk, 7) revisi produk, 8) uji coba pemakaian dan 9) revisi produk.

Jenis data ada 2 yaitu data kualitatif dan kuantitatif. Data kuantitatif berupa angka yang diperoleh dari hasil angket validator, pengguna serta hasil angket respon peserta didik. Data kualitatif berupa saran dan masukan dari para ahli, pengguna serta saran dari peserta didik pada saat uji coba. Sumber data penelitian ialah dari ahli materi, ahli ahan ajar, guru sebagai pengguna serta peserta didik kelas IV. Teknik pengumpulan data yang digunakan yaitu observasi, wawancara, angket validasi para ahli dan pengguna serta angket respon peserta didik. Observasi dan wawancara dilakukan pada awal penelitian untuk mengetahui potensi dan masalah yang ada di sekolah tersebut. Angket para ahli dan pengguna dibuat untuk 
mengetahui kevalidan produk LKPD berbasis PBL. Angket respon peserta didik dibuat untuk mengetahui kepraktisan dan kemenarikan produk LKPD berbasis PBL.

Angket untuk ahli dan pengguna menggunakan skala likert degan rentang nilai 1-4 seperti pada tabel 1. Angket untuk peserta didik menggunakan Skala Guttman yang terdiri dari jawaban tegas peserta didik yaitu jawaban "ya" dan "tidak" (Sugiyono, 2015).

Tabel 1. Skala Likert untuk validasi ahli materi, ahli bahan ajar, dan guru

(Sugiyono, 2015:135)

\begin{tabular}{lc}
\hline Kriteria & Skor \\
\hline Sangat sesuai & 4 \\
Sesuai & 3 \\
Kurang sesuai & 2 \\
Tidak sesuai & 1 \\
\hline
\end{tabular}

Data yang diperoleh kemudian dianalisi dengan cara mengakumulasikan skor total dari validator ahli bahan ajar, ahli materi, dan pengguna. Data tersebut diolah menjadi bentuk persentase menggunakan rumus yang merujuk dari (Akbar, 2015:82) sebagai berikut.

$V a h=\frac{T s e}{T s h} \times 100 \%$

Keterangan:

Vah $=$ Validasi ahli

Tse $=$ Total skor empirik yang dicapai

Tsh $=$ Total skor empirik yang diharapkan

Skor hasil validasi dari ahli materi, ahli bahan ajar dan pengguna yang berupa persentase selanjutnya dikategorisasikan sepeti pada tabel 2 .

Tabel 2. Kriteria Kategorisasi Hasil Validasi

\begin{tabular}{cll}
\hline Tingkat Pencapaian (\%) & \multicolumn{1}{c}{ Kategori } & \multicolumn{1}{c}{ Keputusan Uji } \\
\hline $85,01-100,00$ & Sangat Valid & Dapat digunakan tanpa revisi \\
$70,01-85,00$ & Cukup Valid & Dapat digunakan, namun perlu revisi \\
$50,01-70,00$ & Kurang Valid & Boleh digunakan dengan revisi besar \\
$01,00-50,00$ & Tidak Valid & Tidak boleh digunakan \\
\hline
\end{tabular}

(Sumber: Akbar, 2015)

Teknik analisis data yang digunakan untuk mengetahui kepraktisan dan kemenarikan berasal dari angket respon peserta didik yang dianalisis menggunakan rumus dari Yamasari (dalam Santoso,dkk 2016) sebagai berikut.

$P=\frac{\sum X}{N} \times 100 \%$

Keterangan

$\mathrm{P}=$ Persentase skor

$\sum \mathrm{x}=$ Jumlah skor

$\mathrm{N}$ = Jumlah skor maksimal 
Jurnal Pembelajaran, Bimbingan, dan Pengelolaan Pendidikan, 1(4), 2021, 254-268

Hasil persentase nilai peserta didik di atas dikategorisasikan sebagai berikut.

Tabel 3. Kriteria Kategorisasi 1 Kepraktisan dan Kemenarikan

\begin{tabular}{cll}
\hline Tingkat Persentase (\%) & \multicolumn{1}{c}{ Kategori } & \multicolumn{1}{c}{ Keputusan Uji } \\
\hline $76 \leq \mathrm{P} \leq 100$ & Sangat praktis/menarik & Dapat digunakan tanpa revisi \\
$51 \leq \mathrm{P} \leq 75$ & Cukup praktis/menarik & Dapat digunakan, namun perlu revisi \\
$26 \leq \mathrm{P} \leq 50$ & Kurang praktis/menarik & Boleh digunakan dengan revisi besar \\
$0 \leq \mathrm{P} \leq 45$ & Tidak praktis/menarik & Tidak boleh digunakan \\
\hline
\end{tabular}

(Sumber : Yamasari (dalam Santoso,dkk 2016)

\section{Hasil dan Pembahasan}

Pengembangan Produk LKPD berbasis PBL mengikuti langkah-langkah metode penelitian sebagai berikut.

\subsection{Potensi dan Masalah}

Hasil observasi menunjukkan bahwa (a) perlunya penambahan kegiatan pada Tema Keragaman Persatuan dan Kesatuan Negeriku Subtema Indahnya Persatuan dan Kesatuan Negeriku pembelajaran 1 dan, (b) peserta didik masih sering mendengarkan penjelasan dari guru, (c) peserta didik cepat merasa bosan karena sering mendengarkan penjelasan dari guru (d) perlu dikembangkan produk LKPD berbasis PBL untuk melatih sikap kerja keras. Hasil wawancara dengan guru kelas 4 menunjukkan bahwa (a) bahan ajar yang digunakan yaitu buku siswa (b) sudah menggunakan K13 saat KBM, (c) kurang adanya sikap kerja keras untuk memecahkan sebuah permasalahan karena masih mengandalkan guru, (d) pada buku siswa tersebut sebenarnya kegiatan sudah sesuai KD, tetapi boleh jika ingin menambahkan kegiatan selain yang ada di buku siswa. Sehingga LKPD ini diharapkan mampu melengkapi buku siswa serta dapat melatih sikap kerja keras peserta didik dalam memecahkan persoalan di LKPD.

\subsection{Pengumpulan Data}

Pengumpulan data dilakukan dengan cara untuk mengetahui potensi dan masalah yang ada di sekolah tersebut berdasarkan wawancara dari guru dan observasi bahan ajar yang telah dilakukan pada langkah sebelumnya serta identifikasi KD untuk menentukan indikator dan tujuan pembelajaran yang akan dicapai. Pengumpulan data yang paling awal dilakukan yaitu dengan cara identifikasi KD. Dikarenakan pengembangan produk LKPD berbasis PBL ini isinya tematik sehingga mengambil muatan IPA dengan KD 3.3 dan 4.3, Bahasa Indonesia dengan KD 3.7 dan 4.7, dan muatan SBDP dengan KD 3.4 dan 4.4.

\subsection{Desain Produk}

Pembuatan desain produk LKPD dilakukan dengan langkah-langkah (a) menentukan KD, tujuan pembelajaran, dan membuat petunjuk penggunaan LKPD (b) membuat rancangan kegiatan di aplikasi MS Word 2013, (c) mendesain cover dan tampilan isi dari LKPD di aplikasi canva (d) memindahkan desain dari aplikasi canva ke MS Word 2013 dan menyusun isi LKPD yang sudah dirancang sebelumnya (e) menyesuaikan tulisan, warna dan gambar pada produk LKPD (f) menyimpan produk LKPD dari yang awalnya MS. Word 2013 disimpan ke PDF (g) mencetak berwarna menggunakan kertas ukuran A4 80 gram, (h) produk siap dikonsultasikan kepada dosen pembimbing, (i) membuat instrumen penilaian untuk ahli materi, ahli bahan ajar, dan pengguna serta membuat angket kepraktisan dan kemenarikan untuk peserta didik. 


\subsection{Validasi Produk}

Hasil penelitian yang diperoleh dipaparkan pada tabel hasil validasi produk oleh para ahli dan pengguna sebagi berikut.

Tabel 4. Rekapitulasi Hasil Validasi Ahli dan Pengguna

\begin{tabular}{|c|c|c|c|c|}
\hline \multirow[b]{2}{*}{ No. } & \multirow[b]{2}{*}{ Aspek Penilaian } & \multicolumn{3}{|c|}{ Persentase Penilaian Validator (\%) } \\
\hline & & Ahli Materi & $\begin{array}{l}\text { Ahli Bahan } \\
\text { Ajar }\end{array}$ & Pengguna \\
\hline 1. & Kelayakan Isi & 92 & - & 100 \\
\hline 2. & Bahasa & 87,5 & - & 100 \\
\hline 3. & $\begin{array}{l}\text { Penguatan Karakter Kerja } \\
\text { Keras }\end{array}$ & 100 & - & 100 \\
\hline 4. & Implementasi Tahapan PBL & 95 & - & 100 \\
\hline 5. & Fisik LKPD & - & 100 & 100 \\
\hline 6. & Tampilan LKPD & - & 100 & 100 \\
\hline 7. & Sistematika LKPD & - & 100 & 100 \\
\hline \multicolumn{2}{|c|}{ Rata-rata } & 94 & 100 & 100 \\
\hline \multicolumn{2}{|c|}{ Kategori Validitas } & Sangat Valid & Sangat Valid & Sangat Valid \\
\hline \multicolumn{2}{|c|}{ Keterangan } & $\begin{array}{l}\text { Tanpa } \\
\text { Revisi }\end{array}$ & Tanpa Revisi & $\begin{array}{l}\text { Tanpa } \\
\text { Revisi }\end{array}$ \\
\hline
\end{tabular}

Berdasarkan hasil validasi produk dari ahli materi diperoleh nilai 94\% dengan kategori sangat valid dan dapat digunakan tanpa revisi. Saran dari ahli materi terkait produk tersebut yaitu dari segi bahasa dibagian komunikatif ahli materi memberikan masukan untuk tata bahasa lebih diperbaiki lagi dan jarak tulisan dengan tepi bawah jangan terlalu dekat sehingga pembaca bisa mudah memahami isinya, untuk cover sampul ditambahkan nama penulis serta dosen pembimbing 1 dan 2, memberikan pertanyaan yang dapat menjawab tujuan dari hasil percobaan yang dilakukan, dan menambahkan percobaan yang berkaitan dengan cara membuat magnet sederhana.

Berdasarkan hasil validasi dari ahli bahan ajar dan pengguna, masing masing memberikan nilai 100\% dengan kategori sangat valid dan dapat digunakan tanpa revisi. Saran dari ahli bahan ajar untuk ukuran font pada KD lebih diperkecil. Saran dari pengguna yaitu menambahakan gambar pada percobaan gaya gesek dan menambahakan soal evaluasi.

\subsection{Revisi Produk}

Untuk penyempurnaan produk LKPD berbasis PBL ini ahli materi, ahli bahan ajar, dan pengguna memberikan saran dan masukan yang membangun. Saran dari ahli materi terkait produk tersebut yaitu dari segi bahasa dibagian komunikatif ahli materi memberikan masukan untuk tata bahasa lebih diperbaiki lagi dan jarak tulisan dengan tepi bawah jangan terlalu dekat sehingga pembaca bisa mudah memahami isinya, untuk cover sampul ditambahkan nama penulis serta dosen pembimbing 1 dan 2, memberikan pertanyaan yang dapat menjawab tujuan dari hasil percobaan yang dilakukan, dan menambahkan percobaan yang berkaitan dengan cara membuat magnet sederhana yaitu dengan cara induksi. Saran dari ahli bahan ajar untuk ukuran font pada KD lebih diperkecil, dari yang semula font berukuran 18 pts, diubah menjadi ukuran 14 pts. Saran dari pengguna yaitu menambahakan gambar pada percobaan gaya gesek dan menambahakan soal evaluasi. 


\subsection{Uji Coba Produk}

Hasil angket respon kepraktisan dan kemenarikan pada saat uji coba produk dengan 6 peserta didik yang mewakili 2 berprestasi tinggi, 2 berprestasi sedang dan 2 berprestasi rendah disajikan pada tabel 5 .

Tabel 5. Hasil Angket Respon Kemenarikan dan Kepraktisan

\begin{tabular}{lllll}
\hline No. & Aspek Penilaian & Nilai & Persentase (\%) & Kategori \\
\hline 1. & Kepraktisan & 34 & 94 & Sangat Praktis \\
2. & Kemenarikan & 35 & 97 & Sangat Menarik \\
3. & Karakter Kerja Keras & 29 & 97 & \\
\hline Jumlah & 98 & 288 & Sangat valid \\
\hline Rata-rata & 5,8 & 96 & \\
\hline Keputusan Uji & Sangat sesuai & Dapat digunakan tanpa revisi \\
\hline
\end{tabular}

Berdasarkan tabel 5, hasil angket respon peserta didik pada saat uji coba produk memperoleh persentase $96 \%$ yang masuk kategori sangat praktis dan sangat menarik serta dengan keputusan uji dapat digunakan tanpa revisi. Saran dari peserta didik untuk produk ini yaitu pemilihan jenis huruf masih ada yang sulit dibaca di halaman 20 , sehingga perlu adanya penggantian jenis huruf.

\subsection{Revisi Produk}

Setelah dilakukan uji coba produk, terlihat pada saat proses pembelajaran terdapat beberapa jenis huruf tepatnya di halaman 20 masih sulit dibaca peserta didik, sehingga produk segera diperbaiki sesuai saran dari peserta didik dengan cara mengganti jenis huruf yang semula tekton pro menjadi century gothic.

\subsection{Uji Coba Pemakaian}

Setelah dilakukan revisi, produk diujicobakan dengan skala belajar yang lebih besar. Hasil angket respon kepraktisan dan kemenarikan pada saat uji coba pemakaian dengan 24 peserta didik disajikan pada tabel 6 .

Tabel 6. Hasil Angket Respon Kepraktisan dan Kemenarikan

\begin{tabular}{lllll}
\hline No. & Aspek Penilaian & Nilai & Persentase (\%) & Kategori \\
\hline 1. & Kepraktisan & 144 & 100 & Sangat Praktis \\
2. & Kemenarikan & 144 & 100 & Sangat Menarik \\
3. & Karakter Kerja Keras & 120 & 100 & \\
\hline Jumlah & 408 & 300 & Sangat valid \\
\hline Rata-rata & 24 & 100 & \\
\hline Keputusan Uji & Sangat sesuai & Dapat digunakan tanpa revisi \\
\hline
\end{tabular}

Berdasarkan tabel 6, hasil angket respon peserta didik pada saat uji coba pemakaian diperoleh persentase $100 \%$ yang masuk kategori sangat praktis dan sangat menarik serta dengan keputusan uji dapat digunakan tanpa revisi. Saran dari peserta didik yaitu lembar penulisan kesimpulan pada lembar jawab belum tersedia. 


\subsection{Revisi Produk}

Setelah dilakukan uji coba pemakaian terdapat lembar penulisan kesimpulan pada lembar jawab belum tersedia. Sehingga produk segera diperbaiki dengan cara menambahkan kolom kesimpulan di lembar jawab.

\subsection{Kevalidan LKPD Berbasis PBL menurut Ahli Materi}

Validasi produk LKPD yang dilakukan oleh ahli materi meliputi 4 aspek yaitu aspek kelayakan isi, bahasa, stimulasi penguatan karakter, dan implementasi model pembelajaran berbasis PBL. Penilaian produk LKPD berbasis PBL dari ahli materi mendapat nilai rata-rata 94\%. Sehingga masuk pada kategori sangat valid dan dapat digunakan tanpa revisi. Hasil validasi ini sudah cukup baik dibandingkan dengan penelitian sebelumnya oleh Rusmalinda, Santoso, \& Pratiwi n.d. (2017) tentang Pengembangan Bahan Ajar Berbasis PBL berupa LKPD disertai Nilai Karakter yang memperoleh hasil validasi dari ahli materi sebesar 85\%. Adapun penjelasan aspek-aspek penilaiannya sebagai berikut.

\subsubsection{Kelayakan isi}

Kelayakan isi masuk kategori sangat valid dengan nilai 92\%. Kelayakan isi ini sudah cukup baik dimana sebelumnya Rachmawati, D. (2017) mengembangkan Bahan Ajar berbasis Problem Based Learning pada Muatan Ipa memperoleh nilai 83,8\% berdasarkan penilaian ahli materi. Aspek ini terdiri dari 3 indikator, yaitu kesesuaian materi dengan KD, kegiatan pada LKPD, dan kemutakhiran materi. Kesesuaian materi pada LKPD telah sesuai dengan KD yang diambil, materi juga sudah sesuai dengan tujuan pembelajaran, serta istilah yang digunakan sudah akurat. Kegiatan pada LKPD juga sudah sesuai dengan tujuan pembelajaran, LKPD sudah bersifat mendorong peserta didik untuk menggali informasi secara berkelompok dan memecahkan masalahnya serta kegiatan LKPD sudah mampu mendorong peserta didik untuk berdiskusi dengan teman sebangkunya.

Kemutakhiran materi pada LKPD menurut ahli materi konsep materi pada LKPD masih kurang mengikuti perkembangan pengetahuan terkini, saran dari ahli materi supaya menambahkan percobaan membuat magnet sederhana dengan cara induksi dimana alat dan bahannya mudah ditemukan, untuk selebihnya gambar ilustrasi sudah sesuai kondisi terkini, dan sudah terdapat contoh dalam kehidupan sehari-hari, serta sudah disertai dengan petunjuk pelaksanaan.

Setelah dilakukan revisi menghasilkan kelayakan isi produk LKPD yang sesuai dengan spesifikasi. Materi pada LKPD sesuai dengan KD yang diambil, yaitu muatan IPA KD 3.3 dan 4.3, muatan Bahasa Indonesi KD 3.7 dan 4.7, muatan SBDP KD 3.4 dan 4.4. Hal ini sejalan dengan pendapat Depdiknas (dalam Arsanti 2018) yaitu salah satu karakteristik bahan ajar adalah materi diakumulasi dari standar kompetensi dan kompetensi dasar yang tertuang dalam kurikulum. KD di atas termuat dalam Permendikbud No. 24 Tahun 2016.

\subsubsection{Bahasa}

Bahasa masuk kategori sangat valid dengan nilai $87,5 \%$. Pada aspek bahasa ini sudah cukup baik dimana sebelumnya Rachmawati, D. (2017) mengembangkan Bahan Ajar berbasis Problem Based Learning pada Muatan Ipa memperoleh nilai 81\% berdasarkan penilaian ahli 
materi. Aspek bahasa terdiri dari 2 indikator, yaitu komunikatif dan kesesuaian dengan kaidah bahasa. Komunikatif dapat diartikan bahasa yang digunakan sudah jelas, mudah dipahami, singkat dan tidak bertele-tele. Kesesuaian dengan kaidah bahasa untuk ejaan dan penggunaan EYD sudah tepat namun ahli materi memberikan saran pada halaman 2 tulisan dengan tepi bawah sangat dekat, serta penggunaan jenis huruf dan ukuran font yang kurang konsisten dari awal sampai akhir sehingga ahli materi menyarankan adanya jarak antara tulisan dengan tepi bawah dan konsisten menggunakan jenis huruf lebih mempermudah peserta didik dalam membaca.

Setelah dilakukan revisi menghasilkan LKPD yang sesuai dengan spesifikasi. Bahasa yang digunakan dalam LKPD sesuai dengan perkembangan peserta didik dan komunikatif. Hal ini sejalan dengan pendapat Ayuningtyas dkk (dalam Safitri 2018) yaitu salah satu kriteria LKPD yang baik adalah bahasa yang digunakan jelas dan sesuai dengan tingkat kedewasaan siswa.

\subsubsection{Penguatan Karakter Kerja Keras}

Aspek penguatan karakter kerja keras masuk kategori sangat valid dengan nilai 100\%. Produk LKPD ini sudah mampu melatih peserta didik untuk mengerjakan LKPD dengan teliti dan rapi, LKPD sudah bersifat mendorong peserta didik untuk mencari informasi dari sumber belajar lainnya, dan mampu melatih peserta didik untuk tidak menunda-nunda pekerjaan. Hal ini sejalan dengan pendapat Shoimin (dalam Rerung, Sinon, dan Widyaningsih 2017) tentang salah satu kelebihan dari PBL yaitu penggunaan sumber-sumber pengetahuan, baik dari perpustakaan, internet, wawancara, dan observasi pada model ini bisa membiasakan siswa dalam proses pembelajaran.

Aspek penguatan karakter kerja keras pada produk LKPD sudah sesuai dengan spesifikasi. Produk LKPD sudah dilengkapi dengan penguatan karakter kerja keras yang sesuai dengan salah satu indikator kerja keras di antaranya (a) mengerjakan tugas dengan teliti dan rapi, (b) mencari informasi dari sumber di luar sekolah, (c) tugas-tugas dari guru dikerjakan tepat waktu. Hal ini sejalan dengan pendapat Kementerian Pendidikan Nasional 2011 (dalam muryaningsih \& mustadi, 2015) yang menyatakan bahwa indikator kerja keras meliputi (a) setiap tugas dikerjakan dengan teliti, dan rapi, (b) mencari informasi dari sumber di luar sekolah, (c) tugas-tugas dari guru dikerjakan tepat waktu.

\subsubsection{Implementasi tahapan PBL}

Implementasi tahapan PBL masuk kategori sangat valid dengan nilai 95\%. Aspek ini terdiri dari 5 indikator yaitu orientasi, pengorganisasian siswa, bimbingan penyelidikan, pengembangan dan penyajian hasil karya serta evaluasi. Di bagian mengorientasi peserta didik terhadap suatu masalah bahwa pada LKPD sudah terdapat peta konsep yang jelas, tujuan yang jelas, serta LKPD bersifat mengkontruksi pengetahuan dan bukan proses menerima pengetahuan saja. Di bagian mengorganisasikan peserta didik untuk belajar pada LKPD sudah terdapat perintah untuk mengerjakan LKPD secara individu atau kelompok, LKPD sudah bersifat mengarahkan peserta didik untuk menyelesaikan lembar kegiatan, serta sudah terdapat tugas kelompok.

Di bagian membimbing penyelidikan menurut ahli materi masih kurang pertanyaan terkait materi di bawah tabel sebelum menyimpulkan sehingga materi pada LKPD masih 
kurang merangsang peserta didik untuk menciptakan sebuah kesimpulan, untuk selebihnya LKPD sudah mampu bersifat mengarahkan peserta didik untuk berusaha mencari informasi dalam menyelesaikan masalah serta sudah terdapat langkah-langkah atau cara untuk pengerjaan. Hal ini sejalan dengan pendapat pendapat Fathurohman (dalam Dewi dkk, 2017) bahwa pada tahap membimbing penyelidikan individual maupun kelompok terdapat kegiatan mengumpulkan informasi yang sesuai dan melaksanakan percobaan untuk mendapatkan jawaban atas permasalahan yang ada sebelumnya.

Di bagian menyajikan hasil karya LKPD sudah terdapat lembar hasil percobaan yang dilakukan, sudah terdapat lembar penulisan kesimpulan, sudah terdapat lembar jawab untuk menuliskan jawaban. Di bagian mengevaluasi proses pemecahan masalah pada LKPD sudah terdapat kegiatan untuk mengkomunikasikan hasil dari kegiatan, sudah terdapat soal evaluasi di akhir pembelajaran dan terdapat perintah untuk mengumpulkan tugas. Hal ini sejalan dengan pendapat Fathurohman (dalam Dewi dkk, 2017) bahwa pada tahap mengevaluasi terdapat kegiatan refleksi atau evaluasi terhadap penyelidikan mereka dan proses yang mereka gunakan.

Setelah dilakukan revisi pada implemetansi tahapan PBL, menghasilkan produk LKPD yang sesuai dengan spesifikasi. Produk LKPD berbasis PBL harus mengikuti langkah-langkah PBL seperti orientasi, pengorganisasian siswa, bimbingan penyelidikan, pengembangan dan penyajian hasil karya serta evaluasi. Hal ini sejalan dengan pendapat Fathurohman (dalam Dewi dkk, 2017) bahwa tahapan PBL meliputi (1) mengorientasikan peserta didik terhadap suatu masalah, (2) mengorganisasikan peserta didik untuk belajar, (3) membimbing penyelidikan individual maupun kelompok, (4) mengembangkan dan menyajikan hasil karya dan (5) menganalisis dan mengevaluasi proses pemecahan masalah.

\subsection{Kevalidan LKPD Berbasis Problem Based Learning (PBL) menurut Ahli Bahan Ajar.}

Validasi produk LKPD yang dilakukan oleh ahli bahan ajar meliputi aspek fisik LKPD, tampilan LKPD dan sistematika LKPD. Penilaian produk LKPD berbasis PBL mendapat nilai rata-rata $100 \%$. Sehingga masuk pada kategori sangat valid dan dapat digunakan tanpa revisi. Adapun penjelasan aspek-aspek penilaiannya sebagai berikut.

\subsubsection{Fisik LKPD}

Fisik LKPD masuk dalam kategori sangat valid dengan nilai 100\%. Pada aspek ini terdiri dari 2 indikator yaitu keseluruhan LKPD dan tampilan cover LKPD. Di bagian keseluruhan LKPD, LKPD sudah sesuai dengan ukuran yang ditentukan, cetakan sudah berwarna dan jelas serta sudah menggunakan kertas HVS minimal 70 gram. Di bagian tampilan cover LKPD, sudah terdapat gambar ilustrasi yang jelas, terdapat judul dan spesifikasi LKPD, serta sampul sudah menarik karena menggunakan perpaduan warna yang terang seperti warna kuning dan orange. Hal ini sejalan dengan pendapat Ivanandewi, Utami, \& Pratiwi (2019) bahwa memilih warna yang cerah dan berwarna-warni pada LKPD bisa membuat kesan ceria orang yang melihatnya.

Fisik LKPD sudah sesuai dengan spesifikasi. Produk LKPD dicetak berwarna dengan pemilihan warna cerah dan menggunakan kertas ukuran minimal 70 gram, dibagian cover juga sudah didukung oleh gambar ilustrasi yang jelas untuk meningkatkan motivasi belajar peserta 
didik. Hal ini sejalan dengan Ayuningtyas dkk (dalam Safitri 2018) yaitu salah satu kriteria LKPD yang baik adalah LKPD dibuat semenarik mungkin supaya bisa memotivasi siswa untuk mempelajarinya.

\subsubsection{Tampilan LKPD}

Tampilan LKPD masuk dalam kategori sangat valid dengan nilai 100\%. Indikator tampilan LKPD terdiri dari penggunaan jenis huruf, spasi, dan kesesuaian ilustrasi gambar. Di bagian penggunaan huruf, tipe huruf sudah sesuai karakter peserta didik, ukuran huruf mudah dibaca, variasi antara huruf dan judul baik. Tetapi untuk lebih menyempurnakan produk, ahli bahan ajar memberikan saran dan masukan. Pada penulisan KD sebaiknya ukuran huruf lebih diperkecil dari yang semula berukuran 18 pts, menjadi 14 pts. Hal ini sejalan dengan Setiautami (2011) yakni aspek keterbacaan pada bahan ajar bisa terpenuhi apabila dalam pemilihan font menggunakan desain yang sederhana, bersahabat, dan bentuk karakter bulat terbuka.

Di bagian penggunaan spasi jarak antar kata mudah dibaca, jarak antar kalimat tidak terlalu rapat, dan tidak terlalu lebar yang menyebabkan boros tempat. Di bagian kesesuaian ilustrasi dengan gambar, gambar ilusrasi dengan isi sudah sesuai, gambar ilustrasi mudah dipahami, ukuran dan warna gambar proporsional. Hal ini sejalan dengan Ayuningtyas dkk (dalam Safitri 2018) yaitu salah satu kriteria LKPD yang baik adalah tulisan dan gambar harus seimbang, gambar harus cukup besar.

\subsubsection{Sistematika LKPD}

Sistematika LKPD masuk dalam kategori sangat valid dengan nilai 100\%. Pada LKPD sudah terdapat petunjuk penggunaan dan daftar isi, tujuan pembelajaran, peta konsep, tempat untuk menjawab serta terdapat kesimpulan. Hal ini sejalan dengan Ayuningtyas dkk (dalam Safitri 2018:16) yaitu salah satu kriteria LKPD yang baik adalah terdapat tempat yang cukup untuk menjelaskan jawaban atau gambar pada LKPD, memiliki tujuan yang jelas dan bisa memotivasi.

Sistematika LKPD sudah sesuai dengan spesifikasi produk. Produk LKPD berbentuk hard file terdiri dari (a) judul (cover), (b) Kompetensi Inti , (c) Pembelaran ke- (d) Kompetensi Dasar, (e) Peta Konsep, (f) Tujuan Pembelajaran, (g) Petunjuk Penggunaan, (h) Daftar Isi, (i) Isi LKPD (j) Soal Evaluasi. Hal ini sejalan dengan pendapat Azizah (2017) bahwa LKPD disusun dengan memuat judul, petunjuk belajar (petunjuk siswa), kompetensi yang akan dicapai, informasi pendukung, tugas-tugas, dan langkah-langkah kerja,

\subsection{Kevalidan Produk LKPD Berbasis PBL menurut Pengguna.}

Validasi produk LKPD yang dilakukan oleh pengguna meliputi 7 aspek yaitu aspek kelayakan isi, bahasa, stimulasi penguatan karakter, implementasi tahapan PBL, fisik LKPD, tampilan LKPD dan sistematika LKPD. Aspek yang dinilai oleh pengguna merupakan gabungan dari aspek penilaian ahli materi dan ahli bahan ajar. Setelah sebelumnya ahli materi dan ahli bahan ajar memberikan saran terkait produk LKPD, produk segera direvisi untuk selanjutnya divalidasi pengguna. Produk LKPD yang dinilai oleh pengguna masing-masing aspek mendapat nilai $100 \%$ baik dari aspek kelayakan isi sampai aspek sistematika LKDP. Sehingga produk dinyatakan sangat valid dan dapat dignakan tanpa revisi. Saran dari pengguna terkait tampilan 
LKPD yaitu menambahkan gambar percobaan gaya gesek yang akan dilakukan untuk memudahkan siswa dalam melakukan percobaan dan menambahkan soal evaluasi terkait implementasi PBL di bagian evaluasi. Hal ini sejalan dengan Ayuningtyas dkk (dalam Safitri 2018) yaitu salah satu kriteria LKPD yang baik adalah gambar harus cukup besar dan jelas.

Setelah dilakukan revisi sesuai saran dari pengguna, tampilan produk LKPD sudah sesuai dengan spesifikasi. Terdapat contoh gambar percobaan gaya gesek yang akan dilakukan untuk memudahkan peserta didik melakukan percobaan. Sehingga peserta didik saat melakukan percobaan bisa dengan melihat contoh gambar. Hal ini sesuai dengan pendapat Prastowo (dalam Norsanty \& Chairani, 2016) tentang fungsi LKPD salah satunya yaitu memberikan kemudahan bagi peserta didik untuk memahami suatu materi.

\subsection{Kepraktisan dan Kemenarikan Produk LKPD Berbasis PBL menurut Peserta Didik}

Hasil angket respon peserta didik terkait aspek kepraktisan pada saat uji coba produk skala kecil mendapat nilai $94 \%$ dan pada saat uji coba pemakaian skala besar sebesar $100 \%$. Sehingga dapat dinyatakan bahwa LKPD berbasis PBL masuk kategori sangat praktis dengan keputusan uji dapat digunakan tanpa revisi. Penilaian tersebut diperoleh karena sebagian besar peserta didik menyatakan (a) LKPD ini memudahkan dalam belajar, (b) kalimat dalam LKPD mudah dipahami, (c) kata yang digunakan pada LKPD mudah dimengerti, (d) materi yang disajikan mudah dipahami, (e) soal-soal dalam LKPD ini mudah dipahami, (f) seluruh peserta didik dapat mengerjakan soal-soal pada LKPD.

Berdasarkan hasil pengamatan pada saat uji coba didapatkan beberapa temuan sebagai berikut :

1. Dengan adanya LKPD berbasis PBL peserta didik lebih mudah memahami materi tentang pengatahuan baru dari teks bacaan non fiksi, materi tentang gaya magnet, gaya gesek, dan materi tentang seni rupa tempel kolase dan mozaik.

2. LKPD berbasis PBL ini dapat membimbing siswa melakukan percobaan yang berkaitan dengan gaya magnet dan gaya gesek serta ketrampilan untuk membuat seni rupa tempel kolase dan mozaik, sehingga siswa bisa memecahkan permasalahan melalui percobaan yang dilakukan.

Hal tersebut sejalan dengan Trianto (dalam Norsanty and Chairani, 2016) LKPD adalah suatu panduan kegiatan yang digunakan peserta didik untuk menyelidiki dan memecahkan suatu masalah.

Hasil angket respon peserta didik terkait aspek kemenarikan pada saat uji coba produk skala kecil mendapat nilai $97 \%$ dan pada saat uji coba pemakaian skala besar sebesar $100 \%$. Sehingga produk masuk pada kategori sangat menarik dengan keputusan uji dapat digunakan tanpa revisi. Penilaian tersebut diperoleh karena sebagian besar peserta didik menyatakan (a) LKPD berbasis PBL sangat menyenangkan, (b) materi yang disajikan menarik, (c) jenis font dan ukuran huruf yang terdapat dalam LKPD mudah dibaca, (d) gambar-gambar yang terdapat dalam LKPD ini sangat menarik, (e) kegiatan pada LKPD sangat menyenangkan, (f) semua peserta didik menyukai tampilan pada LKPD. 
Berdasarkan hasil pengamatan pada saat uji coba didapatkan beberapa temuan sebagai berikut :

1. Tampilan LKPD dari segi perpaduan warna orange, putih, merah dan kuning sangat menarik bagi siswa sehingga meningkatkan keinginan siswa untuk belajar.

2. Gambar-gambar animasi yang terdapat di lembar kegiatan pada LKPD sangat menarik bagi siswa.

Hasil dari uji coba produk dan pemakaian sesuai dengan pendapat Ayuningtyas dkk (dalam Safitri 2018) yaitu salah satu kriteria LKPD yang baik adalah tampilan LKPD harus lebih menarik dan menyenangkan untuk meningkatkan motivasi siswa.

Tetapi untuk lebih menyempurnakan produk, peserta didik memberikan saran baik pada saat uji coba produk maupun pemakaian. Saran atau komentar dari peserta didik pada saat uji coba produk yaitu pemilihan jenis huruf masih ada yang sulit dibaca di halaman 20 , sehingga perlu adanya penggantian jenis huruf. Saran atau komentar dari peserta didik pada saat uji coba pemakaian yaitu lembar penulisan kesimpulan pada lembar jawab belum tersedia sehingga perlu adanya penambahan kolom penulisan kesimpulan

\subsection{Karakter Kerja Keras pada Produk LKPD Berbasis PBL}

Penilaian kerja keras ini dinilai oleh ahli materi, pengguna dan peserta didik. Penilaian karakter kerja keras yang dinilai oleh ahli materi dan pengguna menilai tentang penerapan karakter kerja keras di dalam produk LKPD berbasis PBL yang dipelajari peserta didik. Penilaian ini meliputi bahwa LKPD berbasis PBL (a) melatih peserta didik untuk mengerjakan LKPD dengan teliti dan rapi, (b) mendorong peserta didik untuk mencari informasi dari sumber belajar lainnya, (c) melatih peserta didik untuk tidak menunda-nunda pekerjaan. Berdasarkan hasil validasi ahli materi dan pengguna memberikan nilai sebesar $100 \%$ yang masuk dalam kategori sangat valid.

Karakter kerja keras dalam menggunakan LKPD berbasis PBL diperoleh dari angket kerja keras yang diberikan kepada peserta didik. Angket kerja keras tersebut menilai tentang (a) seluruh LKPD dikerjakan dengan teliti dan rapi, (b) mencari informasi dari sumber-sumber lain yang berkaitan dengan perintah pada LKPD, (c) tidak menunda-nunda pengerjaan LKPD yang diberikan guru (d) tetap fokus pada LKPD yang diberikan guru (e) mencatat dengan sungguh-sungguh segala sesuatu yang telah dikerjakan.

Kerja keras siswa pada saat uji coba produk skala kecil mendapatkan nilai $97 \%$ dan pada saat uji coba pemakaian skala besar mendapat nilai $100 \%$. Hal ini sejalan dengan pendapat Kementerian Pendidikan Nasional 2011 (dalam muryaningsih \& mustadi, 2015:194) yang menyatakan bahwa indikator kerja keras meliputi (a) setiap tugas dikerjakan dengan teliti dan rapi, (b) mencari informasi dari sumber di luar sekolah, (c) tugas-tugas dari guru dikerjakan tepat waktu, (d) fokus pada tugas-tugas yang diberikan guru di kelas, (e) mencatat dengan sungguh-sungguh sesuatu yang dibaca, diamati, dan didengar untuk kegiatan kelas.

\section{Simpulan}

Berdasarkan pembahasan dapat disimpulkan bahwa penelitian dan pengembangan ini menghasilkan produk berupa LKPD berbasis PBL dengan Penguatan Karakter Kerja Keras Subtema Indahnya Persatuan dan Kesatuan Negeriku di Kelas IV SDN Banggle 2 Kabupaten 
Blitar yang valid, praktis, dan menarik. Validitas produk sebesar $98 \%$ berdasarkan rata-rata penilaian oleh ahli materi, ahli bahan ajar, dan pengguna. Sedangkan kepraktisan dan kemenarikan produk pada saat uji coba produk sebesar $96 \%$ dan uji coba pemakaian sebesar $100 \%$ berdasarkan penilaian peserta didik. Maka produk LKPD berbasis PBL ini sudah sesuai dengan tujuan pembelajaran yaitu valid menurut ahli materi, ahli bahan ajar, dan pengguna, serta praktis dan menarik menurut peserta didik. Sehingga produk layak digunakan dalam pembelajaran.

Saran untuk penelitian lebih lanjut yaitu dikarenakan adanya keterbatasan waktu dan biaya pelaksanaan penelitian dan pengembangan yang menggunakan model Borg and Gall ini terbatas hanya sampai 9 tahapan, sehingga disarankan pada pengembangan produk lebih lanjut bisa sampai pada tahap 10 yaitu produksi massal dengan ketentuan melakukan uji coba produk dengan skala yang lebih luas (disejumlah SD diberbagai lokasi). Produk LKPD berbasis PBL ini juga masih dinilai oleh 1 ahli materi, 1 ahli bahan ajar dan 1 pengguna, sehingga disarankan pada pengembangan produk lebih lanjut sebaiknya dilakukan validasi skala luas (beberapa validator).

\section{Daftar Rujukan}

Akbar, S. (2015). Instrumen Perangkat Pembelajaran. Bandung:PT.Remaja Rosda Karya.

Arsanti, M. (2018). Pengembangan Bahan Ajar Mata Kuliah Penulisan Kreatif Bermuatan Nilai-Nilai Pendidikan Karakter Religius Bagi Mahasiswa Prodi PBSI, FKIP, UNISSULA. Jurnal Kredo. 1(2), 71-90.

Azizah, I. N. (2017). Lembar Kerja Peserta Didik Materi Aritmatika Sosial dengan Model Pengembangan Thiagarajan. Numerical: Jurnal Matematika dan Pendidikan Matematika, 63-72.

Dewi, N. M. J., Putra, D. K. N. S., Ganing, N. N., \& Hum, M. (2017). Pengaruh Model Pembelajaran Problem Based Learning Berbantuan Media Audio Visual Animasi terhadap Hasil Belajar IPA. MIMBAR PGSD Undiksha, 5(2).

Fitri, Y., \& Octarini, H. 2017. Pengembangan Handout Dengan Pendekatan Problem Based Learning (PBL) untuk Meningkatkan Kemampuan Pemahaman Konsep Matematika Siswa Kelas VII SMP Negeri 25 Padang. THEOREMS (THE jOuRnal of mathEMatics), 2(1), 86-99.

Ivanandewi, S. A., Utami, B. S., \& Pratiwi, P. (2019). Edukasi Jajan Sehat pada Anak Usia 6-9 Tahun di Salatiga Lewat Buku Interaktif. Jurnal Kesehatan Kusuma Husada, 77-84.

Muryaningsih, S., \& Mustadi, A. (2015). Pengembangan RPP Tematik-Integratif untuk Meningkatkan Karakter Kerja Keras di Kelas 1 SD N 2 Sokaraja Tengah. Jurnal Prima Edukasia, 3(2), 190-201.

Norsanty, U. O., \& Chairani, Z. (2016). Pengembangan lembar kerja siswa (LKS) materi lingkaran berbasis pembelajaran guided discovery untuk siswa SMP kelas VIII. Math Didactic: Jurnal Pendidikan Matematika, 2(1), 12-23.

Rerung, N., Sinon, I. L., \& Widyaningsih, S. W. (2017). Penerapan model pembelajaran Problem Based Learning (PBL) untuk meningkatkan hasil belajar peserta didik SMA pada materi usaha dan energi. Jurnal Ilmiah Pendidikan Fisika Al-Biruni, 6(1), 47-55.

Rachmawati, D. (2017). Pengembangan Bahan Ajar Berbasis Problem Based Learning Pada Muatan Pelajaran Ipa Kelas Iv Sdn 01 Kalipancur Kabupaten Pekalongan. Doctoral dissertation, Universitas Negeri Semarang.

Rusmalinda, R., Santoso, H., \& Pratiwi, D. (2017). Pengembangan Bahan Ajar Berbasis Pbl Berupa Lkpd Disertai Nilai Karakter. Lampung: Universitas Muhammadiyah Metro.

Safitri, A. 2018. Pengembangan Lembar Kerja Peserta Didik Berbasis Collaborative Teamwork Learning Pada Materi Fluida Dinamis.

Santoso, K. S. (2016). Pengembangan Multimedia Interaktif Perubahan dan Pelestarian Lingkungan Berbasis Pendekatan Ilmiah untuk Siswa Kelas X SMA Negeri 1 Lawang. Skripsi. Jurusan Biologi-Fakultas MIPA UM.

Setiautami, D. (2011). Eksperimen Tipografi dalam Visual untuk Anak. Humaniora, 2(1), 311-317. 
Jurnal Pembelajaran, Bimbingan, dan Pengelolaan Pendidikan, 1(4), 2021, 254-268

Sudrajat, A. (2011). Mengapa Pendidikan Karakter?. Jurnal Pendidikan Karakter.

Sugiyono, S. (2015). Metode Penelitian Pendidikan; Pendidikan Kuantitatif, Kualitatif, dan R\&D. Bandung: Penerbit Alfabeta.

Susanto, A. (2016). Teori Belajar dan Pembelajaran. Jakarta: Prenadamedia Group.

Yaumi, M. (2014). Pendidikan Karakter (Landasan, Pilar, dan Implementasi). Jakarta: Prenadamedia Group. 